\title{
Borderland Child Heterotopias. A Case Study on the Belgian-German Borderlands
}

\section{Machteld Venken}

To cite this article: Machteld Venken (2020): Borderland Child Heterotopias. A Case Study on the Belgian-German Borderlands, Journal of Borderlands Studies, DOI: 10.1080/08865655.2020.1824679

To link to this article: https://doi.org/10.1080/08865655.2020.1824679
(c) 2020 The Author(s). Published by Informa UK Limited, trading as Taylor \& Francis Group

曲 Published online: 24 Sep 2020.

Submit your article to this journal $\sqsubset \pi$

山 Article views: 85

Q View related articles $\sqsubset$

View Crossmark data $\nearrow$ 


\title{
Borderland Child Heterotopias. A Case Study on the Belgian- German Borderlands
}

\author{
Machteld Venken \\ University of Luxembourg, Luxembourg
}

\begin{abstract}
This article investigates the capacities of children to participate actively in their lives in the Belgian-German borderlands in the time period between World War I and World War II. The article interprets a body of historical sources that has hitherto been left unexplored - namely, borderland child ego documents - with the help of insights from child studies and border studies. These ego documents unfold as borderland child heterotopias. Borderland child heterotopias include material places and creative linguistic loci established by or for those considered in crisis in relation to the rest of society based on their age within or outside child spaces of modernity. The borderland child heterotopias offer a unique gateway to borderland children's past imaginations for a better world.
\end{abstract}

\section{KEYWORDS}

Belgium; Germany; borderlands; heterotopia; child agency; history

\section{Introduction}

As the anthropologists Spyrou and Christou have noted, children are "linked with the power struggles that accompany the processes that give rise to, maintain, and transform borders and their role in the world" $(2014,2)$. Case study research on the history of children in borderlands revealed that states, upon acquiring new pieces of land near their political borders, invested their hopes in child policies in order to raise a generation of socially engaged citizens able to bring the periphery closer to the country's core (Präger 2015; Mezger 2016). In order to understand how individual children reacted to such policies, researchers have used the oral history method. The testimonies of adults recalling their childhood years in borderlands after World War II, for example, have revealed that children were more flexible than adults in adopting, and adapting to, the premises of a postwar reality (Wylegała 2015).

Deepening the investigation into the capacities of borderland children to participate actively in and report about the world in which they lived, the author asks what scholars today can learn from historical sources that have hitherto been left unexplored by researchers. What happens if materials composed by borderland children in the interwar years are put at the center of the analysis? This article presents the argument that so-called

CONTACT Machteld Venken machteld.venken@uni.lu Centre for Contemporary and Digital History (C2DH) UNIVERSITÉ DU LUXEMBOURG Belval Campus Maison des Sciences Humaines 11, Porte des Sciences L-4366 Esch-Belval Luxembourg

(c) 2020 The Author(s). Published by Informa UK Limited, trading as Taylor \& Francis Group

This is an Open Access article distributed under the terms of the Creative Commons Attribution License (http://creativecommons.org/ licenses/by/4.0/), which permits unrestricted use, distribution, and reproduction in any medium, provided the original work is properly cited. 
historical ego documents (such as a letter, a youth magazine, or a diary) authored by borderland children offer a different gateway to examine their opportunities to articulate acceptance, refusal or propositions of change to the environment they encountered in a time of uncertainty regarding the future state sovereignty of the Belgian-German borderlands in the years between World War I and World War II.

The article uses Michel Foucault's concept of a heterotopia, which has been appropriated by border scholars (Pugliese 2009; Konrad and Nicol 2011; Green 2012; Lafazani 2013) in order to interpret the materials produced by children in the past. By introducing the notion of the borderland child heterotopia, the paper emphasizes that age mattered. The interwar Belgian-German borderlands harbored child spaces of modernity in which child writers could take an active role in the shaping of their everyday lives. In contrast to adults, these child writers articulated creative solutions to overcome the uncertainty about the state sovereignty of their home grounds. A reading of borderland child heterotopias, therefore, gives us a different gateway to the past; they open up the past imaginations of borderland children.

After an introduction to Foucault's notion of heterotopia and the way it has been used in interdisciplinary research on borderlands, borderland child heterotopias are defined and explained. What follows is a presentation of the specific historical context the BelgianGerman borderlands found themselves in at the end of the 1930s, as well as a clarification of the author's selection and reading of those historical sources foregrounding the agency of borderland children. The article then continues with an in-depth analysis of the literary oeuvre of three borderland child writers, before showing in the conclusion how the notion of borderland child heterotopias can contribute to border studies and historical research.

\section{Borderlands and heterotopias}

Michel Foucault referred briefly to the term heterotopia in his book The Order of Things (1970) and elaborated on it in his published speech "Of Other Spaces" (1986). He put forward six principles of heterotopias. First, he considered heterotopias a constant feature in most societies, but that "in civilizations without boats, dreams dry up, espionage takes the place of adventure, and the police take the place of pirates" (Foucault 1986, 27). More specifically, according to another of Michel Foucault's principles, heterotopias appear among individuals encountering a temporal rupture with their conventional lives. The next principle is the appearance of heterotopias as spaces with restricted access, which may seem to be open, but which have exclusion mechanisms. Heterotopias also offer a temporary world harboring "several sites that are in themselves incompatible" (Foucault 1986, 25). Heterotopias often provide an inversion of the meaning of a given space, with the purpose either to invent a parallel space where life is more organized than in the everyday confusion or to expose the profound cleavages within a certain system of power. According to the last principle, Michel Foucault's heterotopias are places that relate to all other places in a society (Foucault 1986, 27).

Border scholars have used Michel Foucault's notion of a heterotopia in order to interpret the complexities related to bordering processes. In borderlands, when state border lines become less distinct and categories of the inside and outside become more diffuse, Sarah Green wrote: "the source of the distinctions that borders mark (the differences that make a difference) are not condensed into an abstract line at the edge of a place, 
but are located elsewhere" (Green 2012, 587). Sarah Green contrasted heterotopias with utopias (non-existent spaces where life is beautiful), citing Foucault's description of them as real but external spaces, where "all the other real sites that can be found within the culture are simultaneously represented, contested, and inverted" (Foucault 1986, 24). "One proposed example of a heterotopia would be islands. Functioning both as places where asylum seekers arrive and as luxury holiday destinations for tourists, they are "spaces that can accommodate simultaneously often violently contradictory differences" (Pugliese 2009, 663).

Border scholars have almost exclusively referred to heterotopias as material places. However, whereas in "Of Other Spaces" Foucault described heterotopias as "real places - that do exist and that are formed in the very founding of society" (Foucault 1986, 24), in The Order of Things he referred to heterotopias as linguistic places: "heterotopias desiccate speech, stop words in their tracks, contest the very possibility of grammar at its source; they dissolve our myths and sterilize the lyricism of our sentences" (Foucault 2002, xix). Kelvin T. Knight, investigating an overlooked radio broadcast by Foucault, moreover, expressed an insight that is probably unfamiliar to border scholars: that the concept of the heterotopia "was never intended to refer to real sites, but rather pertains exclusively to textual representations of these sites" (Knight 2017, 141). In this article, a heterotopia is referred to either as a material place (a real site) or as a linguistic place (a text taking the form of a literary source and representing a real site).

Although Foucault described heterotopias as a "constant of every human group", he was convinced heterotopias were more likely to appear among groups considered in crisis compared to the rest of society (Foucault 1986, 24). Angie Voela has already indicated how "in the past women were able to resort to crisis heterotopias, places suitable for re-examining femininity as an object of desire and for fashioning new forms of subjectivity" (Voela 2011, 168). Taking this argument further, this article will examine whether borderland child heterotopias were "places suitable for re-examining" childhood.

\section{Borderland child heterotopias}

The definition of a child used in this article is inspired by Michel Foucault's idea of groups in crisis. An introduction into the historical development of childhood will make this clear. Throughout the Europe of the nineteenth century and the beginning of the twentieth century, efforts were made to create children as a social group: to establish age borders and make cohorts of children experience an increasing part of their childhood in specially designed child spaces. Thanks to a prohibition of child labor, children's time was devoted to new forms of socialization, such as in schools and youth organizations. Children received different opportunities in special spaces set aside from the world of adults, and increasingly experienced situations differently than adults (Sandin 2010). Child spaces of modernity could include members and acquaintances with biological ages exceeding the legal definition of a child at the time. Interwar Belgian law differentiated between a schoolchild (aged between six and fourteen), a working child (from fourteen years old), and majority (sexual majority at the age of sixteen, juridical at eighteen, and civil at twenty-one) (Jamin and Perrin 2005, 159-162).

In historical sources from the interwar years, adults did not refer to children in terms of belonging to a specific biological age cohort; instead, they at times considered that 
members of a youth organization - irrespective of their actual age - were children in a state of crisis in relation to the human environment. ${ }^{1}$ Therefore, most of the borderland children focused on in this article are here called children because their written output was found within the archival collection of a youth organization. The actual biological age of these children was considered less relevant at the time and was not always mentioned. The historical ego document of one borderland child was added to the analysis, even though we do know neither whether the girl belonged to a youth organization, nor what her biological age was; in her letter, she called herself an "underage child" 2 . This borderland girl was included because she sent out a written description of what she considered to have been a crisis in her family, an action no adult in her environment undertook at the time. Because she offered a different perspective on everyday life than borderland adults, we will see that German civil servants valued her creative written output as a source of information.

Children in the past were indeed not only "simply beings" but also "significantly doings" (Oswell 2012, 3). The British sociologist David Oswell has stated that children's activities are often presented "in terms of the local, the face to face, the interpersonal", despite the fact that relationships between children cut across different scales: adult interventions, government policy, notions of childhood and infrastructure (Oswell 2012, 268). The Finnish social scientists Kirsi Kallio and Jouni Häkli, in turn, have demonstrated how children are omitted in a traditional understanding of political agency congruent with "rational intentional action concerning collective matters known to have political relevance, practiced by actors who are capable of understanding and acting on the issues at stake through official or semi-official channels" (Kallio and Häkli 2013, 7). The authors encourage researchers "to find politics in people's experienced and practiced worlds" and to investigate how "children's access to politics relates to growing awareness in public matters, the emancipation of the subject and more inclusive policy-making" (3, 4). The British philosopher David Archard, moreover, indicated that Western thought traditionally assumed a connection between adulthood and rationality, which made it logical to consider the acquisition of reason decisive for a coming of age, and to consider children deprived of the (full) capacity to act rationally. Archard proposes an alternative definition in which children can come to possess "a mind of their own", while having to rely on the networks of adults to proliferate their ideas (Archard 2014, 4).

The above-mentioned insights on the creation of child spaces of modernity, as well as children's capacities to participate actively in their environment, shape the definition of a borderland child heterotopia. Borderland child heterotopias are referred to in this article as including material places and creative linguistic loci established by or for those considered in crisis in relation to the rest of their borderland society based on their age within or outside child spaces of modernity. These material places did not incorporate the entire Belgian-German borderlands but were limited to the places where children experienced their lives and could express themselves.

\section{The Belgian-German borderlands in the interwar years}

Whereas studying "a place where two entities (usually nations or societies) border each other" has been most common in borderlands studies, this article foregrounds a temporal dimension of borderlands and studies "what happens when distinct societies [...] contest 
lands in between" within a specific time period in the past (Duval 2010, 3). The BelgianGerman borderlands are defined as the lands that belonged to Germany and switched to Belgian state sovereignty after World War I ended, while still being contested by people in Germany and by borderland inhabitants. The Belgian-German borderlands consist of the region of Eupen, the region of Sankt Vith, and the region of Malmedy (hereinafter ESM). Most local inhabitants remained and exchanged German for Belgian citizenship. Approximately six percent of the population, around 4,800 people, emigrated to Germany, and a smaller number of professionals, including teachers (whose number amounted to 68 in ESM in the year 1925), moved from other parts of Belgium to ESM (Lejeune, Rauw and Jousten 2019, 244-260). Local inhabitants from the regions of Eupen and Sankt Vith could continue using the German language while communicating with Belgian state authorities, whereas inhabitants from the region of Malmedy needed to approach state representatives in French. The German-speaking children of local inhabitants from the regions of Eupen and Sankt Vith, who were born as Belgian citizens, are the focus of this inquiry.

This article focuses on the Belgian-German borderlands in the years between World War I and World War II. Soon after the February Revolution had come to an end, the Petrograd Soviet started to speak of self-determination and peace. Imperial paternalism needed to be exchanged for national self-determination. The Western Allies condemned the German expansionism formulated in the Brest-Litovsk Peace Treaty of March 1918 and responded by making the dissolution of imperial regimes and the self-determination of people in Central and Eastern Europe their war aims (Sanborn 2014, 236). After the war, statesmen and diplomats gathered in France to lay out the conditions of peace. Situating the cause of the war in Prussian militarism and the autocratic ruling style of the Hohenzollern dynasty, Woodrow Wilson argued that Germany's power needed to be restricted. The principle of self-determination Woodrow Wilson so vehemently supported was often given a national interpretation and used as an authoritative rhetorical means by parties involved at the negotiation tables in Paris (Cattaruzza and Langewiesche 2012, 4). The Treaty of Versailles prescribed (instead of a plebiscite, as happened in the DanishGerman borderlands of North Schleswig) a public consultation in order to determine the state sovereignty of ESM. Borderland inhabitants considered this consultation an infringement of their perceived right to self-determination and continued to contest the consultation throughout the interwar years (O'Connell 2018, 4).

Initially, ESM functioned as a separate administrative entity with colonially inspired rule. One year after the regions had been included in the Belgian province of Liège in 1925, Belgian politicians secretly tried to sell the regions of Eupen and Sankt Vith back to Germany, but the Great Powers put a halt to the negotiations. The historian Victor O'Connell recently came to the seemingly paradoxical conclusion that, for as long as ESM was under colonial rule, there was a policy, whereas as soon as they were administratively integrated within the Belgian Kingdom, their future was in the hands of politicians often acting opportunistically in order to keep their own heads above water within fragile and rapidly changing coalition governments $(2018,291)$. Borderland inhabitants were indeed confused about the kind of integration Belgian statesmen had in mind and expressed that feeling in their voting behavior; parties demanding a new consultation on self-determination received 75 per cent of the vote in 1929 (Lentz 2000, 333). On the other hand, Belgium was in an economically better position than Germany and - 
especially during the recession at the end of the 1920s and the first half of the 1930s offered borderland inhabitants more social benefits than its neighbor.

After the National Socialists seized power in 1933, Germany massively increased its support for activities preserving the language and culture of what it considered its countrymen living abroad, out of the conviction that borderland inhabitants belonged to the German Volk (people). Financial support issued by the German Ministry of Foreign Affairs through its Reichszentrale für Heimatdienst (Reich Central Office for Domestic Propaganda), and later by the German Ministry of the Interior through the Verein für das Deutschtum im Ausland (Association for Germanness Abroad) for German-minded cultural organizations in ESM had already amounted to 60,000 Reichsmark yearly at the end of the 1920s, but by the end of the 1930s, this sum had increased to 113,200 Reichsmark, the equivalent of 765,000 USD in 2019, and was provided by the Nationalsozialistische Deutsche Arbeiterpartei (National Socialist German Workers' Party or NSDAP), which had forced the VDA into political conformity, with the clear aim to influence borderland inhabitants ideologically and politically (Lejeune 1992, 120-137; Kartheuser 2001, 108). The coordinator of most of that aid was the German civil servant Franz Thedieck, who closely cooperated with the VDA (Brüll 2013). ${ }^{3}$

In 1936, German military forces violated the international agreements made in Versailles in 1919 and in Locarno in 1926, and put its troops into the demilitarized zone on the German side of the Belgian-German state border. Belgian politicians faced parliamentary elections in May 1936, which brought parties denouncing parliamentary democracy almost a quarter of the votes, some of them condemning Belgium's vassalage towards France. Embarking on a neutral course, Belgian statesmen buried their promise to offer France military assistance in the case of a German invasion and started bilateral negotiations with Germany (Gérard 2006, 1040). The Belgian-German borderlands were systematically kept out of the bilateral talks in the late 1930s, as both German and Belgian state representatives considered them currency to pay off a supposedly imminent geopolitical deal (Hyde 1937, 126). Initially, borderland inhabitants adopted "a wait and see approach" during this period of uncertainty (O'Connell 2018, 144). By the end of the 1930s, however, that option was no longer possible given the increased politicization of public life, a breakdown in communication between borderland adults wanting to remain part of Belgium and those wanting reunification with Germany, and the (characteristically Belgian) pillarization of social and cultural life along ideological profiles (mainly Catholic, socialist or liberal) gradually reaching out to more spheres of the lifeworlds of borderland inhabitants (Christmann 1974, 506; Kartheuser 2001, 148). In 1939, for the first time, revisionist parties in ESM received less than half of the votes in the parliamentary elections (Lentz 2000, 333). Although most of the voters had expressed the will to remain under Belgian state sovereignty, Germany annexed ESM in May 1940.

Germany eventually annexed all the territories it had lost after World War I (with the exception of North Schleswig). Following World War II, more or less the same pieces of lands switched state sovereignty again (with the exception of Poland, where the changes were greater). However, attitudes toward ethnic and linguistic minorities changed. An ethnically clean nation-state was now deemed most desirable, with minorities being considered "a cause of conflict per se" who should no longer be granted the privilege to use their language and nourish cultural contacts with people across the political border (Lemberg 2000, 179). 
Children have mostly been left undiscussed in the historiography on the BelgianGerman borderlands, and the existing work focuses on the policies designed by adults for children (Lejeune 1989). Using a different methodological approach makes it possible to include the sources children produced themselves into our understanding of the borderlands' past.

\section{Methodology}

This article analyzes the creative written output of children who grew up in the BelgianGerman borderlands in the interwar period. That output is referred to as borderland child ego documents. The borderland child ego documents composed in the interwar period are analyzed as historical sources. At the heart of a historical analysis is a contextualization of the creation process, meaning and outreach of archival sources in their time and place. Childhood historians have been asking whether there is something that makes the historical analysis of sources composed by children different. The cognitive, linguistic and emotional boundaries of children have long been used as an argument against exploring children's voices throughout history. Children were not thought to be rational, which, according to Mary Jo Maynes, has long been at the heart of many historians' definition of a social actor $(2008,114)$. Today, however, scholars "often denounce the general theory of human agency called rational choice" (Aya 2001, 143) and pay more attention to the practices of people who differed from each other regarding gender, age, class and race (Little 2017). There are methodological challenges in finding out how children viewed their treatment by adults, how they articulated this experience in their own practices, and how they recall(ed) it in sources historians have access to today. Child historians agree that the contextualization of the labor that went into the facilitating, hindering or prohibiting of expressions of children in the past allows us to uncover children's descriptions of interpersonal relations and everyday life conditions. In this way, the insights of children contribute to the reconstruction of a fuller picture of the past (Stargardt 1998; Blessing 2006).

In a global history of girlhood, the editors remarked: “to uncover girls' agency, we are forced to deal with the paucity of sources left behind by children and youth, especially by girls in cultures where female education was not well established [...] children as a rule are some of history's most silent subjects. [...] Scholars who wish to uncover girls' voices must be methodologically creative" (Helgren and Vasconcellos 2010, 3-4). A similar statement can be made about children's agency in the Belgian-German borderlands in the interwar years. The scarcity of borderland child ego documents is a given, as is the need for an interdisciplinary analysis of them.

The borderland child ego documents this article presents were discovered during the research for a systematic comparison of children's past in the Belgian-German and Polish-German borderlands (Venken 2021). The author consulted the literature, read archival sources written by or related to borderland children in fifteen archives across Europe, and analyzed press articles. Not all regional sources survived World War II, as the French-speaking school of Eupen, for example, was set on fire during the German invasion in 1940, and Sankt Vith and Malmedy were bombed during Hitler's last offensive in 1944-45. Interwar sources produced at the Belgian national level were disappointingly meager. The archives of Belgian governmental cabinets and the Belgian 
Ministry of Education were practically non-existent (Depaepe, de Vroede, and Simon 1991, 371). In much better condition were German archives reporting on the institutions and historical actors involved in contacts with borderland inhabitants, such as the documents of Franz Thedieck, the Special Consultant of the German Reich's Home Office for ESM throughout the 1930s. Diplomatic archives in Brussels and Berlin provided information about the child policies directed towards the borderlands.

\section{Three borderland child writers}

The author discovered the oeuvre of three borderland child writers. The historical ego documents of two writers were created within a youth organization. Youth organizations were a new phenomenon in the 1930s in ESM, and although they enjoyed growing acclaim, they remained marginal phenomena. Youth organizations operated as structures where children could express themselves under the watchful eye of adults (Depaepe 1998, 146). Pro-Belgian youth organizations such as the scouts were a grassroots phenomenon, although they also enjoyed the approval of Belgian statesmen. ${ }^{4}$ The number of scout members never equaled that of pro-German youth organizations (Pfadfinder Obere Weser 1991, 26). Our first borderland child writer is Lubi, a boy who saw his letter published in the "Scouting Corner", the only bulletin published by a youth organization in ESM in the interwar years (Lubi 1939). Lubi was the only ordinary scout whose letter was printed. Pro-German youth organizations were coordinated by Karl Pütz, who was made responsible for youth work in ESM within the German Ministry of the Interior and worked under Franz Thedieck's supervision. Among a total population of around 60,000 borderland inhabitants, these revisionist youth organizations gathered 120 members in 1934, and increased their ranks to 660 by 1938 (Wiesemes 1995a, 1995b). Our second borderland child writer is Billy Bredohl, the leader of a pro-German youth organization for girls. Her diary and a private letter were found in the only archived collection of borderland child documents in $\mathrm{ESM}^{5}$.

The third borderland child writer is an anonymous girl. Since in Belgium adults had a decisive say on how children were turned from spoken children into speaking children until the 1960s, we need to rely on the rare historical actors such as this third borderland child writer in order to glimpse beyond the control of adults over the way children articulated their knowledge, practices, emotions and imaginations (Depaepe 1998, 146; Oswell $2012,3)$. Nevertheless, she composed and sent out her letter without the knowledge of her parents. The letter illustrates how hard it is to gain access to child sources not supported or directly provoked by adults. The girl wrote: "I am writing this while my mother is taking a walk with my aunt" and "I may not give any names, or else my father is going to beat me up". ${ }^{6}$ Her letter is the only ego source we possess today shedding light on the everyday life within interwar families from the perspective of a borderland child. Discovering the existence of such a letter does not happen often and was something of a thrill for the author of this article.

The ego documents composed by these three borderland child writers contain or refer to four child heterotopias. The diary of Billy Bredohl was partly written at a youth hostel, which, as we will see below, was a material place specifically designed for the young and operating as a heterotopia. The other three borderland child ego documents are linguistic loci functioning as child heterotopias. One common feature of the four child heterotopias 
is Michel Foucault's principle of time; the writers arrived "at a sort of absolute break with their traditional time" (Foucault 1986, 26). The child heterotopias are multifaceted responses to - and were prompted by - the competition between opinions, facilities or infrastructural networks offered by pro-German and pro-Belgian actors to borderland inhabitants in the late 1930s, which appears to have triggered the borderland children into articulating a stance, predominantly within the newly established youth organizations.

The creative literary output of our borderland child writers is not representative of how children acted in the past. Most borderland children never wrote letters, did not keep a diary, did not join a youth organization, and left school at the age of fourteen. ${ }^{7}$ Nevertheless, the author considers the oeuvre of borderland child heterotopias meaningful. First, the work of the borderland child writers reached out within, and sometimes beyond, their environment. Lubi's letter was printed in the "Scouting Corner", a column that functioned as the mouthpiece of the scouting movement. Billy Bredohl was the head of an approximately hundred-strong youth organization. And the letter of the anonymous girl was circulated within the German state administration because civil servant Karl Pütz believed her description offered an insight into the situation in borderland families. Second, although these individual child writers did not discuss their activities with each other, they all put forward alternative solutions for life in the borderlands at a time of uncertainty.

\section{Lubi}

We will now analyze the literary output of the three borderland child writers successively. A week before the outbreak of the Second World War, a scout named Lubi (a member of the scout group of Saint Georg in Eupen) had his handwritten letter published in the "Scouting Corner" section of the borderland daily newspaper Grenz-Echo. Between August and December 1939, scouting leaders in ESM ran a one-page section in a newspaper that advocated the equal use of languages (as had been laid down in the Belgian constitution) and spread the message that the German language deserved equal treatment within the Belgian Kingdom (Pabst 2007, 195).

Scouting was founded in the border region in 1933 by the borderland inhabitant Jean Rentgens (1914-57), who became acquainted with scouting during his education to become a priest in a seminary elsewhere in Belgium ${ }^{8}$. The scouting movement was established in 1907 by Robert Baden-Powell after becoming aware that his books on scout training for the military were also being read by children. Scouting was to help children acquire the desired skills of an exemplary future citizen through adventure, physical training and social learning (Mechling 2013, 423).

The "Scouting Corner" is an example of a borderland child heterotopia as a textual representation of borderland scouting composed at the brink of World War II and harboring "several sites that are in themselves incompatible" (Foucault 1986, 25). The pro-Belgian adults who ran this section intended it to be a neutral, parallel space where children were given the opportunity to escape the tensions over the region's future sovereignty status that marked everyday life in the borderlands in the second half of 1939. However, as a result of their cooperation with the daily Grenz-Echo, scouts in ESM were accused of being pro-Belgian. In an open letter written in December 1939, scouting 
leaders attempted to defend themselves, arguing that they had an apolitical profile (Pfadfinder Obere Weser 1991, 17). In a society where adults could no longer prevent politics from infiltrating more and more aspects of their everyday lives, the scouts publicly claimed a neutral stance. Nevertheless, the attacks continued and the section was dropped from the newspaper later that month.

In his letter, Lubi reported how his scouting leader, who worked for the Grenz-Echo, had asked him to publish a letter he had composed at the summer camp and sent to his aunt. Summer camps were a new phenomenon for borderland children in the late 1930s, with 130 boy scouts attending them in $1938 .{ }^{9}$ Instead of writing about his own exploration, which was essential to scouting ideology, Lubi focused on the activities of his adult caregivers. He wrote about how a "brown monk from Brazil" paid the scouts a visit to their summer camp, reporting that scouts in Brazil were allowed to shoot monkeys when they disturbed their summer $\operatorname{camp}^{10}$ (Illustration 1 (Lubi 1939, 1)).

The boy was invited to become a speaking child in the printed public sphere of ESM, as a member of a youth organization that put almost exclusively Catholic upper- and middle-

\section{Brief an meine Tante}

Side Tante Emalle!

Der rebenleter (Du tennit bas Ter fa... weift Du unier truherer Begarletter mit orm grauen Solstud. Der lebt ben lawarsen Mod trögt unb in ber Begirtaleitung ift; Da töfs er allerbent bructen). Stebe- Tente, ber TrabenFeber tral mid bieler Tage aul oer Etrabe, als in gerabe lür IRutter in phand Eourrtreut boten ging Da babe id suerit mal bie Saden gufammenge|dolagen to bait, Dalb bas Eaner. traut beinabe in bis Golfe gerollt wäre, unt meinen IAneibigiten Orubs gemodt. Da lagte ber Mabenjeder: -Du, Eubl. Katribft $D_{11}$ nod immar Detner olten Ionte mit ber grînen Frille uns oem Rapottbittden - - Tanle Imaliel? fiet id begriftert tin, $\rightarrow 0$ la, ber kbreibe ih nod oftle - - Plun, Bubt, oa wirbeft Du mir cisen groben Gefallen han, weins Du fie mid suerit iflen lafst. (Esine Betlle nutidte sto fabrilih auf oie Berbernafe...) SA miltbe fie mir benn abjarriben Für oie giebfinterede tm

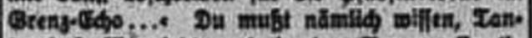
te, Dal Bir lett aud in Ber Tagesproile fo nemat mein effiftent bes Brang-C6o, id meib nidt merum...) uns bemertbar moden. Dit

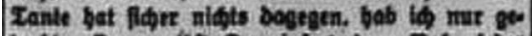
dodt. Dann gibft Du einlad Dem Kabenleort

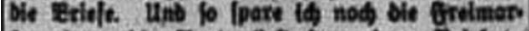
tea, benn bis Tente fleft fo meinen Brief in ber Sethane foin, wos? Ulber wean Da mis bann gurile (Áribit, Iante, lo barif Du bas nidht fur 8ettuns ididen, weil Bie Beute ba Did nod nids tentien.

Figeniles liebe Zente, wollte id Dit thas Don meinem tebten 8oger in Baneden ergäbien.

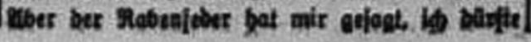

mur 4 Geliten fipreiben, fonft baltes if fe teinen Fiat in ber 8eling. Jange. Tante, wir batten einen fotnen Früles im Bager! gBeift Du, lonen braunen Pater aus bem Barnjtod. Eigent. nid ift or earnidst aus bem Barnftod, landern aus Braftiten. Da mobnen Diefe EifientI Det. Tuma (out brefilianild bells bas Extberlowe. So beifft ndimld ber \$ater). Der \$amta bat uns, pief oon ben Bfien mabit. Benn bie ein Blabjinserleger im urnato finden, bann if bas fitr fie ein Sesteritrabl Darum ftellen sle Blab. finber in Prafliten Be glade mit Gemebr vors Baper, un be efflen taputisulditelen. Edjabe.

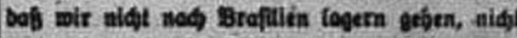
wabr, Iante? Der. Bater tann aud to laböa fingen cuf brafiBantik Das ift noh oiet lidj. ner, als menn Du rguter grono.... fiaght Darift mur aths bole lein Yante, weil id Dit bes larelter. Du bift la not sibst in Bra: pifien bel oen riflen gridelen.

Setet babe id aber fapon ble 4. Eeite nollge. Ibriben. Madfitumal libribe is Die aben eines langen Britf. Des merben fie lhon in Ole Seltung tritogen. Bon mit abors Bager: aud wieber lantbon, tide Zants Iimalite Deln Edine plospinbernefle. But:.

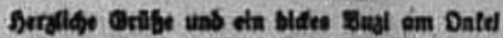
Tebopblit und an metne grouftar Mojalder.

Illustration 1. The "Scouting Corner" in the borderland daily Grenz-Echo on 23 August 1939 with Lubi's letter to his aunt. 
class children, a majority of whom were boys, under the watchful eye of the Roman Catholic Church. With National Socialism reigning in neighboring Germany, the scouts aimed to raise future citizens who would be prepared to take up apostolic duties for a society in which the freedom of religion was respected. According to the borderland scouts, scouting did not stand for direct political engagement, even though it implicitly respected the Belgian nation-state (Pfadfinder Obere Weser 1991, 59). Karl Pütz at the German Ministry of the Interior, however, interpreted the borderland scouts' activities as political: "What the state Catholic education prepares mentally and culturally is politically and ideologically completed in Belgian scouting". "Lubi's words do not offer us an insight into whether the boy considered himself a politically engaged agent or not, and that was most probably the purpose of the scouting leader's decision to print his letter. The banal story of an obedient child was supposed to demonstrate the scouts' neutral stance in an increasingly politicized environment. In other words, recalling how his scouting leaders had entertained him, instead of referring to the self-government and social learning so crucial to the ideology of Baden-Powell, Lubi showed himself as faithful to the dogmatic Catholic ideas of his local caregivers. This leaves us with an image of borderland scouting as a child space of modernity where children could experience life differently than adults; but whether it also functioned as a space "suitable for re-examining" childhood through the emancipation of scout members, and whether "new forms of subjectivity” were fashioned, was never reported in historical sources (Voela 2011, 168).

\section{Sibylle Bredohl}

In the mid-1930s, Sibylle (Billy) Bredohl, born in 1919 in Eupen, established and ran the hiking group Frohe Mädel Eupen (the Merry Girls of Eupen - hereinafter FM). Billy also coordinated the work of all revisionist borderland girls' organizations in ESM (Schenk 1997, 191). In 1936, Karl Pütz advised Billy to temper her enthusiasm in setting up her own activities. ${ }^{12}$ Within Germany, where membership to the National Socialist Bund Deutscher Mädel (League of German Girls - hereinafter BDM) was mandatory, authorities could demote girls whose practices deviated from the expected totalitarian, disciplining norm from leaders to ordinary members. In ESM, however, Karl Pütz could do no more than send Billy the BDM journal Mädel in Dienst (Girl on Duty) for self-study, and hope she would translate National Socialist ideology into the activities of her youth organization. ${ }^{13}$ Nevertheless, by 1937, Pütz had begun to intensify his cooperation with Billy Bredohl because talented organizers in ESM were difficult to find (Schenk 1997, 195).

Billy organized activities in the property of her father, Bernard Bredohl, the owner of a spa hotel and one of the most important logistic centers for revisionist activities in the 1930s. Officially, he was an ordinary member of the Heimatbund, an organization promoting cultural ties with Germany, but in reality he also offered support to political organizations with a National Socialist agenda, most prominently the Homeland Loyalty Front (Heimattreue Front - hereinafter HF). In 1934, Belgian authorities had passed a law on the basis of which Belgian inhabitants could have their Belgian citizenship revoked if they were found to have seriously undermined democratic principles. This law was used in 1935 to make four members of the HF leave for Germany. Billy's father knew that, while Belgian authorities could, in principle, allow public cultural activities, they 
viewed with suspicion the mobilization of borderland inhabitants for a National Socialist agenda. He knew what to say and what to keep silent, teaching his daughter how to do likewise.

Billy's private archive provides an insight into how she developed her activities along different scales. ${ }^{14}$ Billy not only separated her activities between the open and the hidden but also practiced different translation strategies between the different scales on which she developed her activities. Billy articulated different relationships to borderland inhabitants, her father, her father's friend, borderland soldiers in the Belgian army, and the German Ministry of Interior, all the while managing to stay out of the spotlight of Belgian security authorities. She deliberately publicized her cultural activities, and kept hidden her more politically oriented activities. Three documents from Billy's personal archive demonstrate in detail how she did this.

The first document is a printed invitation. In November 1937, Billy premiered a theatrical play she had written for an open-air festival of her organization in the city of Eupen. Titled You Belong Where Your Homeland Is!", the play featured "the lost child" as the main character. Billy had the invitations printed by her father. The play was performed by members aged between fifteen and eighteen, and preceded by songs and dances performed by the younger members, the Küken (aged between two and ten) and the Jungmädel (ten to fourteen) (Ruland 2013, 29) (Illustration $2^{15}$ ).

Whereas Billy chose to stage the theatrical play in the open, she decided to locate other activities further away from the public eye, in a youth hostel in the village of Hauset ${ }^{16}$. Her diary reveals that in the summer of 1939, she organized a training course for forty borderland girls here ${ }^{17}$. The hostel was funded by a regular visitor to Bernard Bredohl's hotel, Peter Bohlen, in 1934. Having renovated the building first with secret financial support from Germany, he then joined the Federation of Belgian Hostels and received Belgian state subsidies. The hostel welcomed not only regular Belgian tourists but also members of the German National Socialist mandatory youth organization for boys, the Hitlerjugend, dressed as civilians. At other times, it hosted schooling weekends for revisionist borderland youth organization leaders such as Billy.

The youth hostel can be viewed as a material place functioning as a child heterotopia. This heterotopia held similarities with what Victor Konrad and Heather N. Nicol characterized as cross-border heterotopias in the Mexican-American borderlands. Cross-border heterotopias are brought about through "a cross-border community sharing of cultural facilities and institutions among residents of a common ethnic origin, which link different 'nationalities' bridging a boundary". This "enables ideological extremes to coexist in proximity and sustains a mosaic of cultural production in uncertain space" (Konrad and Nicol 2011, 82-83). Although the youth hostel existed at another moment in time, the scope of its activities was limited to the building and the surrounding woods, and only involved members of pro-German youth organizations, it was the place where the cross-border nature of borderlands generated its effects. Here, members of the HF and the German Hitlerjugend, along with other pro-German borderland youth organizations, could freely communicate with each other and organize joint training sessions (Schenk 1997, 294).

The hostel operated in a space which seemed to be open for the public but to which access was nevertheless restricted. It was situated deeply hidden in the woods, and although it officially operated as a public institution recognized by the Belgian Tourist 


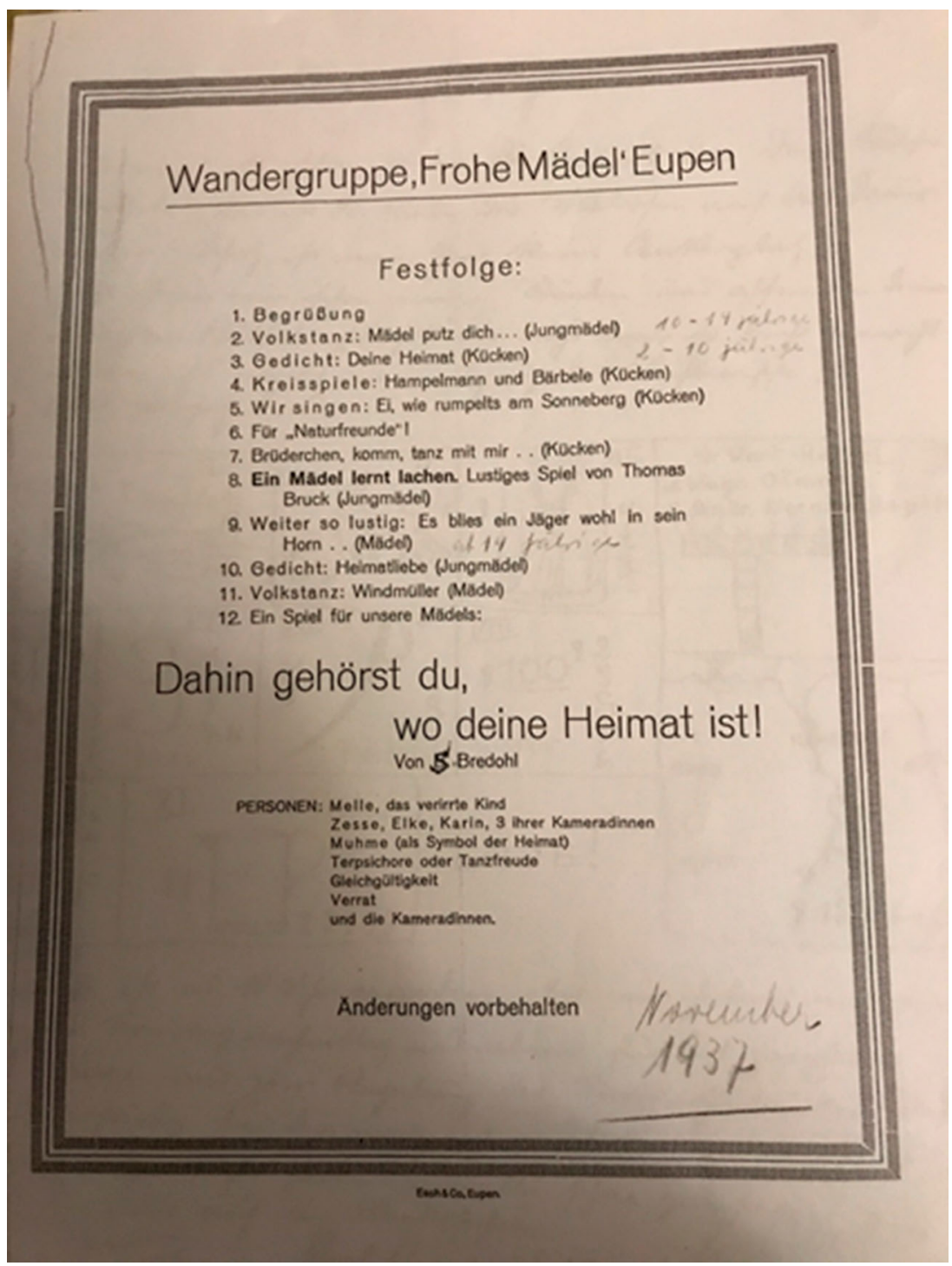

Illustration 2. The invitation for the premiere of Sibylle Bredohl's self-written play "You Belong Where Your Homeland Is!" (November 1937).

Association, it also organized closed meetings for youth organizations that were kept secret from that association (Schenk 1997, 294). It also functioned as a parallel space where children could find a temporary refuge from the everyday confusion that characterized life in ESM in the late 1930s. Established and approved by adults as another space where children were given the opportunity to live in harmony, unburdened by the imperfect actuality of adult life, the hostel could have functioned similarly to what we know about contemporary child heterotopias. While historians have not discussed child heterotopias, Sara McNamee has demonstrated how video games for children provide an adultcreated and adult-approved parallel digital space where children can "resist and escape the control" over the organization of their lives $(2000,479)$. 
The purpose of the youth hostel, however, was not merely to provide a place where children could escape control over the organization of their lives, but also to relate to other places in the society in which it operated. Yang fleshed out this principle of Michel Foucault in her description of heterotopias as: "places that are different from yet ambivalently connected with the rest of society, and where imagination interacted with the real"; they are characterized by "a desire to ardently prepare, if not purely for the future, then for the birth of a constructive attitude toward building a more sensible and livable world" (Yang 2018 , 13). The activities at the youth hostel involved training for a cause in the future. The bodies and minds of those such as Billy Bredhol and the other FM members were strengthened according to an imagined National Socialist ideal. Given the restricted access to, as well as the hidden character of, this borderland child heterotopia, and the fact that it ceased to exist more than 70 years ago, a researcher today faces a difficult task in ascertaining whether the purpose of the youth hostel back then was also to "offer a constructive attitude" (13). Whereas the youth hostel in Hauset was indeed set up as a "place suitable for re-examining" childhood, the question whether "new forms of subjectivity" were fashioned will always remain unclear (Voela 2011, 168). Today, we can only speculate what may have caused Billy to advance to the function of deputy leader of the BDM section of the Province of Cologne-Aix-la-Chapelle after Germany's invasion of Belgium in 1940 (Ruland 2013, 51). Was she capable of adapting well to German youth organizational structures or did she enrich these organizations with the new insights she had developed during her activities at the youth hostel in the late 1930s?

Equally hidden to the public eye remained Billy's correspondence service with young borderland men during their obligatory military service in the Belgian army. She received, among other items of correspondence, a letter from three such soldiers in October 1939, when the Second World War had already broken out in Poland. That letter is the third document of Billy's we discuss in this article. The archived letter includes a borderland child heterotopia in the form of a crossword. Billy was invited to fill in that crossword in order to decode a highly controversial secret message composed by soldiers serving a neutral country: "Our soul for the devil - our heart for the girls - our life for Adolf Hitler" (Illustration $3^{18}$ ).

Borderland soldiers enrolled in the Belgian army sent their declarations of loyalty to Adolf Hitler to Billy by the regular French- and Dutch-speaking national post service, but hid their message in a crossword to be deciphered in the German language. This child heterotopia offered a temporary world harboring "several sites that are in themselves incompatible" (Foucault 1986, 25). The crossword inverted the meaning of the soldiers' service to the Belgian army by mixing up the political categories of belonging and articulating radical fragmentation. Historians do not have enough information today to answer the question how the borderland soldiers' "imagination interacted with the real" (Yang 2018, 13). The untenable tension between borderland soldiers enrolled in the Belgian army but endorsing National Socialism was resolved a couple of months after the crossword was drawn when, following the German invasion of the Belgian-German borderlands in 1940, borderland inhabitants were granted German citizenship, and local men were enrolled in the German army (Quadflieg 2008).

Despite the development of activities that were suspicious from the viewpoint of Belgian authorities, Billy managed to remain out of their spotlights. When in November 1939, the Belgian Ministry of Transports forbade its civil servants and their children to 


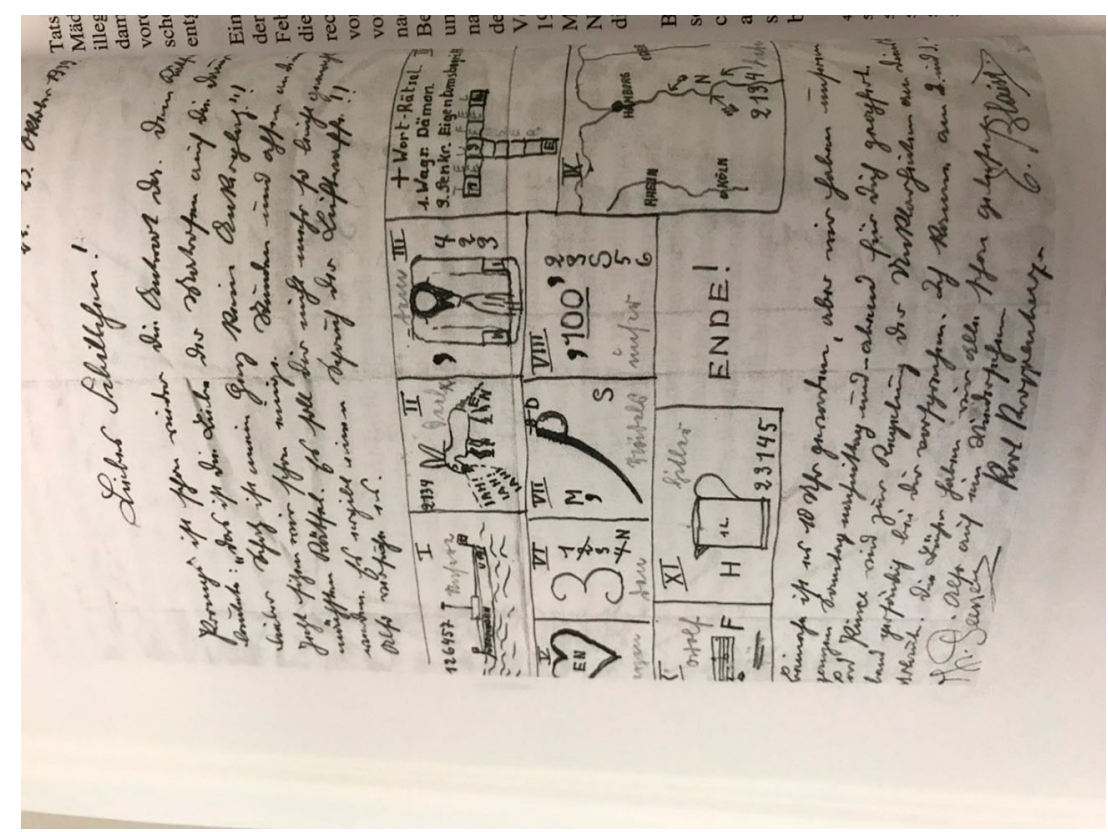

Illustration 3. Borderland soldiers enrolled in the Belgian army sent this letter to their "lovely Sibylle" in October 1939.

enroll in what it considered anti-national borderland organizations, on the proscribed list were both the organizations her father was active in, the Heimatbund and the HF, but not Billy's FM (Kartheuser 2001, 144-148). While this meant Billy had been successful in playing on different scales and using accurate translation strategies, it could additionally point to the fact that Belgian state authorities considered a youth organization less harmful than its adult counterparts.

After the war, Billy was charged with collaborationism, convicted, and imprisoned. She encountered a Belgian collaborationist from Flanders in prison, with whom she moved to Germany when both were released in the early 1950s (Ruland 2013,56). In a rare interview conducted in the 1990s, she claimed: "We, frohe Mädel, were connected with the Heimatbund [...] The Heimattreue Front tried to integrate us [...], which I always vehemently rejected" (Velden-Bredhol 1994, 6). Again, Billy was revealing here only part of her past experiences. In the 1930s, she took an active role in interpreting the lines between a pro-German attitude and a National Socialist conviction, between the public and the private sphere, in a much more multidimensional way. Thanks to the help of her father's friend and the German Ministry of Interior, she could become actively involved in juggling ways of layered apprehension across the different scales of her activities.

\section{An anonymous girl}

The last borderland child ego document discussed in this article is the letter of an anonymous girl from Eupen, written on October 18 1938, to Adolf Hitler. The girl revealed the different narratives the borderland adults in her family were articulating. Her father "says I 
am now a Belgian, and I should honor those whose bread I am eating, what would Hitler say if people didn't honor him and publicly offended him", while her mother was oriented towards Germany (heimattreu). Her aunt, a visiting German citizen, in contrast, scoffed that HF leaders, whom she deemed "louts", were paid with German taxpayers' money, and advised the girl's family to prefer the higher living standards in Belgium rather than wish to join poor Germany. The girl reported the family situation this had led to: "and so we children often sit together in a corner, crying because our parents are bickering and screaming" (Illustration $4^{19}$ ).

The anonymous girl from Eupen wanted to establish peace in the family, and thought she could convince Hitler with her arguments: "Dear Führer, I once heard you saying on the radio that you were also just a poor soldier once, so you must also feel the pain for everyone." She continued: "It [Eupen] is really just a small town, think about how nice the English [and] French were to you and how they gave you the Sudeten territories only to save everyone's life". Based on that argument, she dared to invite Hitler to "talk in favor of us on the radio, say clearly that you do not want Eupen-Malmedy St. Vith any longer, tell them we are peaceful". ${ }^{20}$

The letter is an example of a borderland child heterotopia composed without the support of adults. It is a textual representation of a family home as experienced and spontaneously expressed by a borderland girl. In contrast to the youth hostel and the scouts' column, but similar to the soldiers' letter, the letter of the anonymous girl exposed the severe cleavages of the everyday confusion and articulated these in a way unutterable in public by adults at the time.

The girl's action may be interpreted as irrational. Who did she think she was to offer a dictator like Adolf Hitler her advice? And why would she put her own aunt in danger?

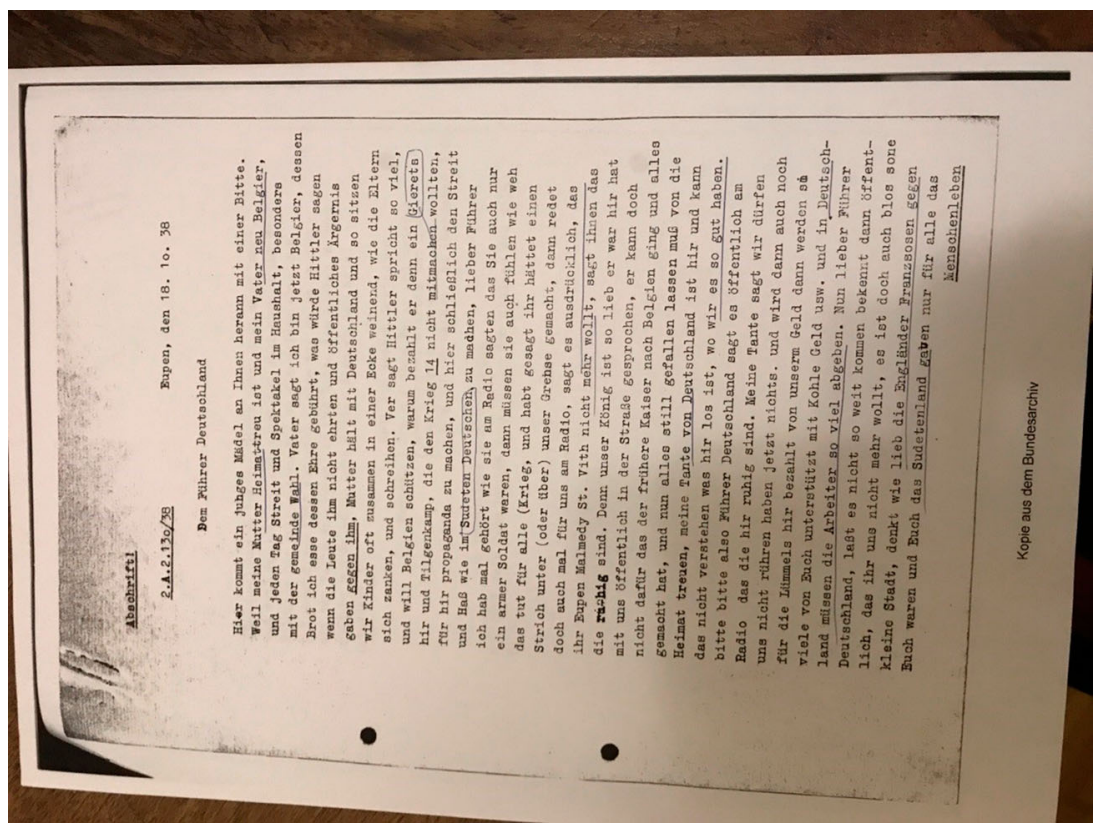

Illustration 4. The letter of an anonymous girl from Eupen to Adolf Hitler in October 1938. 
How should we, indeed, assess the literary imagination of her borderland child heterotopia? Yang suggests that in heterotopias, "the literary imagination could work in reverse, becoming a viable means by which to mold the intellectual discourse and even the real" $(2018,15)$. The imagined better real world depicted by the anonymous girl in her letter did cause an effect in the real world, albeit different from the one intended.

Back in 1938, the girl's request to be taken seriously ("I worked on this letter for some days") was not ignored. Her handwritten letter received special attention within the German state administration. It was sent from the office of the Chancellor of the Reich, Adolf Hitler, to Karl Pütz. He meticulously transcribed the letter on a typing machine and sent it further to his superior, Franz Thedieck, arguing that: "The letter gives an interesting insight into the political relationships within many Eupenian families. At the same time, the letter sheds a significant light on the influence of many German-speaking relatives visiting Eupen" ${ }^{21}$. In a way, the anonymous girl was considered a rational human being. The letter was valued as a unique source of information, because of the insights it gave into the inconsistent relationships within borderland families, and because the girl did not respect the breakdown in public communication between borderland adults wanting to stay within Belgium and those aspiring to a reunification with Germany in the late 1930s.

\section{Conclusion}

Starting from Spyrou and Christou's recognition of "the constitutive role of children in the social lives of borders and borderlands" (Spyrou and Christou 2014, 2), this article investigated the opportunities of borderland child writers to co-shape their existence in the interwar Belgian-German borderlands. An exploration of hitherto untouched historical sources made it possible to see how children's literary output in the Belgian-German borderlands of the 1930s unfolded in accordance with Michel Foucault's notion of heterotopias. At a time when categories of national belonging became more diffuse, borderland children could create or participate in child-specific material spaces and linguistic loci functioning as other, parallel spaces.

Discovering how borderland child writers had the opportunity to contribute actively to their environment was made possible as a result of a deconstructed understanding of children's agency. Through a widening of the understanding of political agency, Lubi's letter, for example, could reveal itself to be an example of a literary source representing borderland scouting as an activity capable of shaping a neutral political space for children. Interpreting Billy Bredhol's practices as a skillful maneuvering across various scales, as well as a redrawing of the lines between these scales, enabled the author to decipher at which moments, where and how, she could reconsider girlhood with like-minded borderland girls. Moreover, instead of considering an anonymous girl an irrational child, the author found behind the confusing words of her letter a human being capable of independent thinking. Nevertheless, adults often had a decisive say on the ways in which the borderland child writers discussed in this article could convert an opportunity into a way of making a contribution. They decided which children were turned from spoken children into speaking children (as in the case of Lubi) and held decision-making power over the resources needed to proliferate the borderland children's ideas (as in the case of Sibylle Bredhol and the anonymous girl). 
Notwithstanding the effect of the actions of borderland child writers, their literary output provides us with access to their creative solutions to overcome the confusion over the state sovereignty of their environment. Borderland scout Lubi presented himself as a member of an imagined neutral space parallel to the politically deeply divided world of adults. Borderland group leader Billy invested her hopes in an ideal (ized) National Socialist childhood prepared for within the borderland child heterotopia of the youth hostel. And the anonymous borderland girl believed that by advising Adolf Hitler how to proceed, she could secure peace.

It is to be hoped that borderland child heterotopias can contribute to scholarship in border studies and historiography. Whereas heterotopias as a concept have been appropriated by border scholars, no attention has been paid to the situation of children. With children experiencing an increasing amount of their childhood in child spaces of modernity, it is not entirely surprising that borderland child heterotopias could emerge in the interwar Belgian-German borderlands. These borderland child heterotopias, whether they took the form of material or linguistic places, were multifaceted responses provoked by the increased cultural support for youth organizations sent in from Germany, and could be created precisely because borderland children, youngsters and young soldiers found themselves, or were considered to have found themselves, in crisis in relation to the rest of the borderland inhabitants in their environment at the brink of World War II. It ought to be evident that border scholars who are not bound by the scarce traces the past left historians with today possess more possibilities to further develop the notion of borderland child heterotopias presented in this article.

An analysis of borderland child heterotopias also offers up insights that are unavailable in other historical sources, such as archival documents created by adults about the everyday practices of borderland children or interviews conducted with adults who were children in the interwar period. These testimonies were produced at a time when different perceptions on childhood were prevalent and were made by people with very different verbal and abstracting capacities than when they were young. Moreover, rather than conjuring up the past, such accounts tend to take the form of narratives serving to give meaning to that past for the sake of the present (Förderverein 2007). Borderland child heterotopias, however, are uniquely able to open up the past imaginations of borderland children, and in this way enrich our knowledge about the past.

\section{Notes}

1. For example: Anonymous. Sonder-Bericht über das Turn- und Sportfest der Turnerjugend in Sankt Vith am 18. September 1938, Bundesarchiv Koblenz (hereinafter BAK), NL, 174, 23, 1; Auszug aus den Verhandlungen des Schöffenkollegiums, 01.05.1934, SE, 916/62/130; Die Gesandtschaft in Brüssel. Pressebericht, Brüssel, 16/08/1937, The Political Archive of the Federal Foreign Office of Germany, R 102828, 3; Le comité pour la sauvagarde de l'enfance, Aux parents qui entendent, 1934, Nord-Rhein Westfälisches Hauptstaatsarchiv, Reg. Ac., Präs., 1656, II, 6847, 262.

2. Anonymous. Brief an den Führer [von] Deutschland, Eupen, 18/10/1938, BAK, NL, 174, 23 $\mathrm{P}, 5 \mathrm{~b}, 1$.

3. Providing financial support for Volksdeutsche (inhabitants considered to have been of German descent) was also a practice in other regions of Europe. In Polish Upper Silesia, for example, buildings for German-speaking schools were financed by the German Ministry of Foreign Affairs (Falęcki 1970, 97). German mass organisations, such as the Hitlerjugend 
(the mandatory organization for boys under National Socialism), communicated with and traveled to Volksdeutsche (Buddrus 2004, 742-753).

4. Anonymous. Note pour le Premier Ministre. Tableau de la politique suivie dans des cantons d'Eupen, Malmédy et St. Vith pendant 1934, Bruxelles, 13/11/1934, Archives Diplomatiques, B, 331/3, 12 .

5. Private Archive of Herbert Ruland, Eynatten, Belgium (hereinafter RULAND).

6. Anonymous. Brief an den Führer [von] Deutschland, Eupen, 18/10/1938, BAK, NL, 174, 23 P, $5 b, 2$.

7. Not all of the few borderland child ego documents composed in the interwar years contain child heterotopias. For instance, three school essays from 1934 depicting the everyday life of children engaged in such activities as cattle-herding, which were gathered by a local teacher from the village of Büllingen in an unpublished booklet for the highest class, do not meet Foucault's description of a heterotopia, as these are literary representations of practices that were not set apart from, but took place in the everyday reality of the child writers' lives (Lehrpersonen und Elternrat der Gemeindeschule Büllingen 1978, 77-8).

8. Schillings, L. Entre Allemagne et Belgique. La guerre au pays des frontières. Souvenirs personnels des années trente et quarante. Mémoires 1936-1945. Le Mesnil, 2002, 19, Centre for Historical Research and Documentation on War and Contemporary Society, Bruxelles (CEGESOMA), JP 1522.

9. Die belgische Pfadfinderbewegung 1938, Archiv Landesverband Rheinland (hereinafter LVR), Akt 4743.

10. The monk in Lubi's story could have been a Belgian missionary returning from Brazil, as scouting in Brazil was founded in 1910, and Belgian missionaries were active in Latin America at that time. It is, however, most unlikely that the monk had a dark skin color, as it would take until the second half of the twentieth century until Belgians included missionaries of non-European origin. Alternatively, the monk could have been a scouting leader dressed up during a game.

11. Karl Pütz. Die belgische Pfadfinderbewegung in Eupen-Malmedy-St. Vith. Aachen, 24/09/ 1938, LVR, 4744, 50.

12. Karl Pütz. Monatsberichte Februar-März 1936, Aachen, 31/03/1936, BAK, NL, 174, 19, $13 \mathrm{~b}, 5$.

13. Landesleiter Crumbach an Landesrat Hilgers, Düsseldorf, 09/01/1939, LVR, 4735/67.

14. The private archive of Sibylle Bredhol consists of the documents she wrote, letters she received, and photographs of activities of FM (RULAND).

15. Sibylle Bredhol. Programm eines Festes, 11/1937, RULAND.

16. Sibylle Bredhol. Tagebuch, 1938, 26, RULAND.

17. F. Katzan. Schulung der Mädel aus Malmedy und St. Vith, 18/08/1939, LVR, 4745/56, 3.

18. Karl Kroppenberg, E.H.R. Blaise [third unreadable]. An das Liebe Sibillchen, 1939, RULAND.

19. Anonymous. Brief an den Führer [von] Deutschland, Eupen, 18/10/1938, BAK, NL, 174, 23 P, $5 b, 1-2$.

20. After Austria was swallowed up by the Third Reich in March 1938, Hitler expressed his interest in the Czech-German borderlands. In September 1938, the British and the French Prime Minister allowed Nazi Germany to incorporate the Sudetenland, which it did less than a month later.

21. Pütz an Herrn Regierungsrat Thedieck, Aachen, 04/11/1938, BAK, NL, 174, 23 P, 1.

\section{Acknowledgements}

The research for this article was funded by the Austrian Science Fund under the Elise Richter Grant Number V 360 - G 22. The article was written at the Imre Kertesz Kolleg of the Friedrich Schiller University in Jena (Germany) and at the University of Luxembourg (Luxembourg). 


\section{Disclosure statement}

No potential conflict of interest was reported by the author(s).

\section{Funding}

The research for this article was funded by the Austrian Science Fund under the Elise Richter Grant Number V 360 - G 22.

\section{Notes on contributor}

Machteld Venken is a Full Professor of Contemporary Transnational History at the University of Luxembourg. She was trained as a Slavist and historian. She holds a $\mathrm{PhD}$ in history from the Catholic University of Leuven (KU Leuven, Belgium) and a habilitation from the University of Vienna and conducted postdoctoral research in Poland, Germany and Russia. She has published widely on twentieth century European history, including migration history, border regions, comparative and transnational approaches and childhood.

\section{References}

Archard, David. 2014. Children. Rights and Childhood. Abingdon: Routledge.

Aya, Rod. 2001. The Third Man; or, Agency in History; or, Rationality in Revolution. History and Theory 40: 143-152.

Blessing, Benita. 2006. The Antifascist Classroom: Denazification in Soviet-Occupied Germany, 1945-1949. New York: Palgrave Macmillan.

Brüll, Christoph. 2013. Franz Thedieck (1900-1995) - Zeitgenosse des Jahrhunderts. HistorischPolitische Mittelungen. Archiv für Christlich-Demokratische Politik 20, no. 1: 341-70.

Buddrus, Michael. 2004. Totale Erziehung für den totalen Krieg. Hitlerjugend und nationalsozialistische Jugendpolitik. Oldenbourg: De Gruyter.

Cattaruzza, Marina, and Dieter Langewiesche. 2012. Introduction. In Territorial Revisionism and the Allies of Germany in the Second World War. Goals. Expectations. Practices, ed. Marina Cattaruzza, Stefan Dyroff, and Dieter Langewiesche, 1-16. New York/Oxford: Berghahn.

Christmann, Heidi. 1974. Presse und gesellschaftliche Kommunikation in Eupen-Malmedy zwischen den beiden Weltkriegen. Unpublished $\mathrm{PhD}$ Thesis, München.

Depaepe, Marc. 1998. De pedagogisering achterna. Aanzet tot een genealogie van de pedagogische mentaliteit in de voorbije 250 jaar. Leuven: Uitgeverij Acco.

Depaepe, Marc, Maurits De Vroede, and Frank Simon. 1991. The 1936 Curriculum Reform in Belgian Primary Education. Journal of Education Policy 6, no. 4: 371-383.

Duval, Kathleen. 2010. Introduction. In Borderlands: Oxford Bibliograpfhies Online Research Guide, ed. Kathleen Duval, 5. Oxford: Oxford University Press.

Falęcki, Tomasz. 1970. Niemieckie szkolnictwo mniejszościowe na Górnym Śląsku w latach 19221939. Katowice/Kraków: Państwowe Wydawnictwo Naukowe.

Foucault, Michel. 1986. Of Other Spaces. Diacritics 16, no. 1: 22-27.

Foucault, Michel. 2002. The Order of Things. An archeology of the human sciences. London and New York: Routledge Classics.

Förderverein des Archivswesens in der Deutschprachigen Gemeinschaft Belgiens. 2007. In Stellung. Einblicke in das Leben ostbelgischer Dienstmädchen im 20. Jahrhundert: nach Interviews geführt von Reiner Mathieu. Eupen: Grenz-Echo Verlag.

Gérard, Emmanuel. 2006. De democratie gedroomd, begrensd en ondermijnd. 1918-1939. In Nieuwe geschiedenis van België, vol. 2: 1905-1950, ed. Michel Dumoulin, Emmanuel Gérard, Vincent Dujardin, and Mark van den Wijngaert, 869-1118. Tielt: Lannoo.

Green, Sarah. 2012. A Sense of Border. In A Companion to Border Studies, ed. Thomas M. Wilson, and Hastings Donnan, 573-91. Chichester, West Sussex: Blackwell Publishing. 
Helgren, Jennifer, and Coleen A. Vasconcellos, eds. 2010. Girlhood: A Global History. London: Rutgers University Press.

Hyde, Charles Cheney. 1937. Belgium and Neutrality. The American Journal of International Law 31, no. 1: 81-85.

Jamin, Charlotte, and Nathalie Perrin. 2005. Les politiques publiques en matière d'enfance et de jeunesse au XXème siècle, en Belgique et en Communauté française. Liège: Université de Liège.

Kallio, Kirsi P., and Jouni Häkli. 2013. Children and Young People's Politics in Everyday Life. Space and Polity 17, no. 1: 1-16.

Kartheuser, Bruno. 2001. Les années 30 à Eupen-Malmedy. Regard sur le réseau de la subversion. Neundorf: Krautgarten.

Knight, Kelvin T. 2017. Placeless Places: Resolving The Paradox of Foucault's Heterotopia. Textual Practice 31, no. 1: 141-158.

Konrad, Victor, and Heather N. Nicol. 2011. Border Culture, the Boundary Between Canada and the United States of America, and the Advancement of Borderlands Theory. Geopolitics 16, no. 1: 70-90.

Lafazani, Olga. 2013. A Border within a Border: The Migrants' Squatter Settlement in Patras as a Heterotopia. Journal of Borderlands Studies 28, no. 1: 1-13.

Lehrpersonen und Elternrat der Gemeindeschule Büllingen, eds. 1978. 145 Jahre Gemeindeschule Büllingen. Stavelot: Chauveheid.

Lejeune, Carlo. 1989. Abtretung, Umerziehung, Autonomie. Eine politische Schulgeschichte des deutschsprachigen Belgien. In Tafel, Griffel, Rutenstock. 150 Jahre Eifeler Volksschulleben, edited by Arbeitskreis Eifeler Museen, ed. Arbeitskreis Eifeler Museen, 227-242. Meckenheim: Warlich Druck- und Verlagsges.m.b.H.

Lejeune, Carlo. 1992. Die Deutsch-Belgischen Kulturbeziehungen 1925-1980. Wege zur europäischen Integration? Köln/Weimar/Wien: Böhlau.

Lejeune, Carlo, Alfred Rauw, and Wilfried Jousten. 2019. Die grosse Suche nach Heimat und Teilhabe. Wanderungsbewegungen als Spiegel einer unruhigen Zeit. In Grenzerfahrungen. Eine Geschichte der Deutschsprachigen Gemeinschaft Belgiens. Band 4 Staatenwechsel, Identitätskonflikte, Kriegserfahrungen (1919-1945), ed. Carlo Lejeune, Christoph Brüll, and Peter M. Quadflieg, 240-283. Eupen: Grenz-Echo.

Lemberg, Hans. 2000. Grenzen und Minderheiten im östlichen Mitteleuropa - Genese und Wechselwirkungen. In Grenzen in Ostmitteleuropa im 19. und 20. Jahrhundert. Aktuelle Forschungsprobleme, ed. Hans Lemberg, 159-182. Marburg: Herder-Institut.

Lentz, Jochen. 2000. Das Wahlverhalten in den Kantonen Eupen, Malmedy und St. Vith bei den Parlamentswahlen von 1925 bis 1939. Eupen: Förderverein des Archivwesens in der Deutschsprachigen Gemeinschaft VOE.

Little, Daniel. 2017. Philosophy of History. In The Stanford Encyclopedia of Philosophy, ed. Edward N. Zalta. https://plato.stanford.edu/archives/sum2017/entries/history.

Lubi. 1939. "Brief an meine Tante." In Die Pfadfinderecke in Grenz-Echo, August 23, 1.

Maynes, Mary Jo. 2008. Age as a Category of Historical Analysis. History, Agency and Narratives of Childhood. The Journal of the History of Childhood and Youth 1, no. 1: 114-124.

McNamee, Sara. 2000. Foucault's Heterotopia and Children's Everyday Lives. Childhood: A Global Journal of Child Research 7, no. 4: 479-492.

Mechling, Jay. 2013. Children in Scouting and Other Organisations. In The Routledge History of Childhood in the Western World, ed. Paula S. Fass, 419-30. London: Routledge.

Mezger, Caroline. 2016. Entangled Utopias: The Nazi Mobilization of Ethnic German Youths in the Batschka, 1930s-1944. The Journal of the History of Childhood and Youth 9, no. 1: 87-117.

O'Connell, Vincent. 2018. The Annexation of Eupen-Malmedy. Becoming Belgian, 1919-1929. London: Palgrave Macmillan.

Oswell, David. 2012. The Agency of Children. From Family to Global Human Rights. Cambridge: Cambridge University Press.

Pabst, Klaus. 2007. Presse zwischen zwei Weltkriegen (1914-1945). In Zwei Jahrhunderte deutschsprachige Zeitung in Ostbelgien, ed. Heinz Warny, Heinz Godesar, and Alfred Belleflamme, 179210. Eupen: Grenz-Echo. 
Pfadfinder Obere Weser. 1991. Allzeit bereit! Pfadfinder in Ostbelgien. Eupen: Grenz-Echo.

Präger, Ulrike. 2015. 'Musicking' Children from the Bohemian Lands: Nurtured and Hidden Musical Practices on Both Sides of the Iron Curtain Pages. European Review of History 22, no. 2: $310-330$.

Pugliese, Joseph. 2009. Crisis Heterotopias and Border Zones of the Dead. Continuum. Journal of Media \& Cultural Studies 23, no. 5: 663-679.

Quadflieg, Peter M. 2008. Zwangssoldaten und Ons Jongen. Eupen-Malmedy und Luxemburg als Rekrutierungsgebiet der deutschen Wehrmacht im Zweiten Weltkrieg. Aachen: Shaker.

Ruland, Herbert. 2013. "Stets für das Deutschtum eingetreten" oder: Wie aus Eupener "Volkstumskämpfern" der Zwischenkriegszeit Bürger der Bundesrepublik Deutschland wurden. Biographische Notizen zur Bernhard und Billy Bredohl, Josef Thielen und Mine Cremer-Thielen. In Eine Ostbelgische „Stunde Null”? Eliten aus Eupen-Malmedy vor und nach 1944. Annalen des Symposiums im Staatsarchiv in Eupen am 15. September 2012, ed. Christoph Brüll, Els Herrebout, and Peter M. Quadflieg, 21-68. Brüssel: Generalstaatsarchiv.

Sanborn, Joshua. 2014. Imperial Apocalypse. The Great War \& the Destruction of the Russian Empire. Oxford: Oxford University Press.

Sandin, Bengt. 2010. Education. In A Cultural History of Childhood and Family, vol. 5: The Age of Empire 1800-1900, ed. Collin Heywood Collin, 91-110. Oxford/New York: Berg.

Schenk, Katja. 1997. Les mouvements de jeunesse germanophiles dans le canton d'Eupen pendant l'Entre-deux-guerres. Unpublished MA Thesis, Université de Liège.

Spyrou, Spyros, and Miranda Christou, eds. 2014. Children and Borders. London: Palgrave Macmillan.

Stargardt, Nicholas. 1998. Children's Art of the Holocaust. Past and Present 161, no. 1: 191-235.

Velden-Bredhol, Sibylle. 1994. Leserbrief zur N. Rost-Reihe. Rechtsextremismus in der Euregio. Veröffentlichungen der Volkshochschule der Ostkantone 10, no. 1: 6.

Venken, Machteld. 2021 (in print). Peripheries at the Centre. Borderland Schooling in Interwar Europe. New York: Berghahn Books.

Voela, Angie. 2011. Heterotopia Revisited: Foucault and Lacan on Feminine Subjectivity. Subjectivity 4, no. 2: 168-182.

Wiesemes, Eric. 1995a. Die volksdeutsche Jugendbewegung in den Kantonen Malmedy und St. Vith (1933-1940) vol. 1. Zwischen Venn und Schneifel. Zeitschrift für Geschichte, Brauchtum und Kultur. Monatsblätter des Geschichts- und Museumvereins 31, no. 5: 88-91.

Wiesemes, Eric. 1995b. Die volksdeutsche Jugendbewegung in den Kantonen Malmedy und St. Vith (1933-1940) vol. 2. Zwischen Venn und Schneifel. Zeitschrift für Geschichte, Brauchtum und Kultur. Monatsblätter des Geschichts- und Museumvereins 31, no. 6: 11-114.

Wylegała, Anna. 2015. Child Migrants and Deportees from Poland and Ukraine after the Second World War: Experience and Memory. European Review of History 22, no. 2: 292-309.

Yang, Yuqing. 2018. Mystifying China's Southwest Ethnic Borderlands: Harmonious Heterotopia. Lanham: Lexington Books. 